\title{
Immobilization of thermoalkalophilic recombinant esterase enzyme by entrapment in silicate coated Ca-alginate beads and its hydrolytic properties
}

\author{
Seçkin Gülay, Gülşah Şanlı-Mohamed* \\ Izmir Institute of Technology, Science Faculty, Department of Chemistry Gülbahçe Urla, Izmir, Turkey
}

\section{A R T I C L E I N F O}

\section{Article history:}

Received 30 November 2011

Received in revised form 11 January 2012

Accepted 12 January 2012

Available online 31 January 2012

\section{Keywords:}

Esterase

Immobilization

Calcium alginate

Silicate coating

\begin{abstract}
A B S T R A C T
Thermoalkalophilic esterase enzyme from Balçova (Agamemnon) geothermal site were aimed to be immobilized effectively via a simple and cost-effective protocol in silicate coated Calcium alginate (Caalginate) beads by entrapment. The optimal immobilization conditions of enzyme in Ca-alginate beads were investigated and obtained with $2 \%$ alginate using $0.5 \mathrm{mg} / \mathrm{ml}$ enzyme and $0.7 \mathrm{M} \mathrm{CaCl}_{2}$ solution. In order to prevent enzyme from leaking out of the gel beads, Ca-alginate beads were then coated with silicate. Enzyme loading efficiency and immobilization yield for silicate coated beads was determined as $98.1 \%$ and $71.27 \%$, respectively and compared with non-coated ones which were $68.5 \%$ and $45.80 \%$, respectively. Surface morphologies, structure and elemental analysis of both silicate coated and noncoated alginate beads were also compared using Fourier Transform Infrared Spectroscopy (FT-IR) and Scanning Electron Microscope (SEM) equipped with Energy-dispersive X-ray spectroscopy (EDX). Moreover, silicate coated alginate beads enhanced reusability of esterase in continuous processes compared to non-coated beads. The hydrolytic properties of free and immobilized enzyme in terms of storage and thermal stability as well as the effects of the temperature and $\mathrm{pH}$ were determined. It was observed that operational, thermal and storage stabilities of the esterase were increased with immobilization.
\end{abstract}

(c) 2012 Elsevier B.V. All rights reserved.

\section{Introduction}

Esterases (EC 3.1.1.1) belong to the enzyme class of hydrolases and catalyze the hydrolysis of ester bonds, generating alcohol and carboxylic acids. They play an important role in a variety of biotechnological, industrial, environmental and pharmaceutical applications because of their many useful properties [1-3]. Especially, esterases from extremophiles having excellent features are great importance for the utilization of enzyme in a variety of reactions [4-6]. Thermoalkalophilic esterases can perform better in a number of commercial applications compared to other enzymes because of their surprising high resistance against heat and $\mathrm{pH}$.

Although enzymes are excellent tool in a wide range of biotechnological, biomedical, pharmaceutical and industrial applications due to their important catalytic properties, the utilization of them as a free form is not always suitable and optimal for these processes because of their low stability, inhibition by high concentrations of substrates and products, low activity and selectivity toward nonnatural substrates under nonconventional conditions, and so on. Enzyme immobilization technology may be an effective way not only to overcome these unsuitable characteristics but also to allow reuse of enzymes for many reaction cycles of industrial processes.

\footnotetext{
* Corresponding author. Tel.: +90 232 7507618, fax: +90 2327507509.

E-mail address: gulsahsanli@iyte.edu.tr (G. Şanlı-Mohamed).
}

Immobilization of enzymes may offer additional benefits over free enzymes such as possibility of continuous process, controlled product formation, rapid termination of reactions and ease of enzyme removal from the reaction mixture [7].

There are a large number of support materials and methods for the immobilization of enzyme. Entrapment is one of the simplest methods available for enzyme immobilization under mild conditions compared with other immobilization methods [8]. Caalginate beads are one of the most commonly used carriers in the entrapment immobilization of enzymes because of their significant advantages such as good biocompatibility, low cost, availability and resistance to microbial attack [9]. However, there are some disadvantages using this method and support material as well including low mechanical strength, large pore size and leakage of enzyme from beads [10]. Until now, various methods have been proposed to optimize the entrapment efficiency such as coating the surface of alginate beads with cross-linked biopolymers [11-14].

Since esterase enzymes are special interest in a variety of biotechnological applications and utilization of them as a free form is not suitable, in this study, for the first time we have used thermoalkalophilic recombinant esterase enzyme from Balçova Geothermal region [15] for immobilization studies. Enzyme was immobilized effectively via a simple and cost-effective protocol using Ca-alginate by entrapment. The effects of immobilization conditions on enzyme loading efficiency and immobilization yield have been examined and various parameters like concentration 
of alginate, $\mathrm{CaCl}_{2}$ and enzyme were determined in details. In order to overcome leakage of entrapped enzyme, Ca-alginate beads were coated with silicate. As far as we aware, the immobilization of a thermoalkalophilic enzyme by these matrixes has not been reported in the literature. For this purpose, using the optimum immobilization conditions of esterase enzyme in silicate coated Ca-alginate beads, we have determined the hydrolytic properties of immobilized enzyme in terms of storage, operational and thermal stability as well as the effects of the temperature, $\mathrm{pH}$ and bead size on the activity of the immobilized esterase and compared with the free enzyme.

\section{Materials and methods}

\subsection{Enzyme preparation}

Thermoalkalophilic esterase from Geobacillus sp. isolated previously from Balçova (Agamemnon) Geothermal Site in Izmir of Turkey was used in this study [15]. Expression of the recombinant enzyme in Escherichia coli and purification using one step affinity chromatography were carried out according to Tekedar and Şanl1Mohamed [15] procedures.

\subsection{Immobilization of thermoalkalophilic esterase enzyme in Ca-alginate beads}

The most efficient condition of thermoalkalophilic esterase enzyme in Ca-alginate beads were investigated under various \% sodium alginate, $\mathrm{CaCl}_{2}$ and enzyme concentration. Alginate (1-4\%, $\mathrm{w} / \mathrm{v})$ was mixed with Tris- $\mathrm{HCl}$ buffer $(0.1 \mathrm{M}$, at $\mathrm{pH} 8.0)$ for $30 \mathrm{~min}$ at $50{ }^{\circ} \mathrm{C}$. The solution was waited in $4{ }^{\circ} \mathrm{C}$ for $10 \mathrm{~min}$ to eliminate bubbles. Esterase enzyme $(0.01,0.1,0.5$ and $1 \mathrm{mg} / \mathrm{ml})$ was mixed with alginate solution (total $10 \mathrm{ml}$ ) then the mixture was stirred thoroughly to ensure complete mixing for $10 \mathrm{~min}$. As soon as the mixed solution was dripped into $75 \mathrm{ml}$ of $\mathrm{CaCl}_{2}$ solution $(0.1,0.3,0.5,0.7$, 0.9 and $1.1 \mathrm{M}$ ) with a syringe, Ca-alginate beads were formed. After $30 \mathrm{~min}$ of hardening, the beads (more or less 500 beads) were separated from the calcium chloride solution by vacuum filtration and washed on a filter thrice with distilled water. Enzyme loading efficiency (LE) and immobilization yield (IY) was determined according to the equations indicated below:

$\mathrm{LE}=\frac{\text { total esterase }- \text { free esterase }}{\text { total esterase }} \times 100$

$\mathrm{IY}=\frac{\text { specific activity of immobilized Est. }}{\text { specific activity of free Est. }} \times 100$

\subsection{Coating Ca-alginate beads with silicate}

After immobilization of esterase enzyme in Ca-alginate beads, beads were waited in $4 \mathrm{ml} \mathrm{n}$-hexane and $6 \mathrm{ml}$ TEOS (tetraethyl orthosilicate) for $24 \mathrm{~h}$ at room temperature and washed thrice with distilled water.

Silicate coated alginate beads of three different sizes were generated by changing the size of a needle. The diameter of beads was determined with the formula as shown below:

increment in volume $=\frac{4}{3} \times \pi \times(\text { bead diameter })^{3}$

$$
\times \text { number of beads }
$$

Surface structure analysis of esterase immobilized non-coated and silicate coated alginate beads was performed using scanning electron microscope (SEM). The elemental analysis of the noncoated and silicate coated alginate beads were investigated by energy-dispersive X-ray sepectroscopy (EDX). Structural changes in functional groups of alginate beads after coating with silicate were characterized using Fourier Transform Infrared Spectroscopy (FT-IR). Silicate coated and non-coated alginate beads were dried for $1 \mathrm{~h}$ at $50^{\circ} \mathrm{C}$ prior to operation.

\subsection{Hydrolytic activity determination of thermoalkalophilic esterase}

The esterase activity of free and immobilized enzyme was assayed spectrophotometrically using $p$-nitrophenyl acetate $\left(p \mathrm{NPC}_{2}\right)$ as a substrate having one of the best hydrolytic activity among the variety of $p$-nitrophenyl ( $p$-NP) esters [15]. In case of free enzyme, the assay mixture $(1 \mathrm{ml})$ contained $5 \mu \mathrm{l}(50 \mathrm{mM}) \mathrm{pNPC}_{2}$ substrate and $0.1 \mathrm{mg} / \mathrm{ml}$ purified enzyme and initial rates were estimated by measuring the increase in absorbance at $400 \mathrm{~nm}$ as a function of time at $55^{\circ} \mathrm{C}$. For the hydrolytic activity of immobilized enzyme, ten coated beads were placed in a solution of $2985 \mu \mathrm{l}$ Tris- $\mathrm{HCl}$ buffer and $15 \mu \mathrm{l}$ substrate ( $50 \mathrm{mM}$ pNPA) and incubated for $5 \mathrm{~min}$ at $55^{\circ} \mathrm{C}$ and the increase in absorbance at $400 \mathrm{~nm}$ was recorded. Specific activity of immobilized esterase was expressed as initial rate per mg protein entrapped in the beads.

\subsection{Characterization of hydrolytic properties of free and immobilized thermoalkalophilic esterase}

The effect of temperature was tested on hydrolytic properties of free and immobilized thermoalkalophilic esterase by measuring esterase activity at different temperatures $(30,40,50,55,60$, $65,70,75,80$ and $90^{\circ} \mathrm{C}$ ), after 5 min of reaction in Tris- $\mathrm{HCl}$ buffer $(0.1 \mathrm{M}, \mathrm{pH} 8.0)$, and using $\mathrm{NNPC}_{2}$ as substrate. Thermal stability of free and immobilized thermoalkalophilic esterase was evaluated as residual activity under standard assay conditions, after incubation in absence of substrate for $60 \mathrm{~min}$ at $40,50,60,70,80$ and $90^{\circ} \mathrm{C}$ in Tris- $\mathrm{HCl}$ buffer $(0.1 \mathrm{M}, \mathrm{pH}$ 8.0). Enzyme activity prior to incubation was defined as $100 \%$ at each assayed temperature.

The effect of $\mathrm{pH}$ on hydrolytic activity of free and immobilized esterase was determined using $\mathrm{pNPC}_{2}$ as substrate at different $\mathrm{pH}$ values $(4,5,6,6.5,7,8,9,10,11$ and 12$)$, after $5 \mathrm{~min}$ of reaction at $55^{\circ} \mathrm{C}$. The $\mathrm{pH}$ stability was determined by measuring the residual activity under standard assay conditions, after pre-incubation of immobilized esterase for $60 \mathrm{~min}$ at $\mathrm{pH}$ 6.0, 7.0, 8.0, 9.0, 10 and 11.0. Enzyme activity prior to incubation was defined as $100 \%$ at each assayed $\mathrm{pH}$.

The reusability of immobilized esterase enzyme with silicate coated versus non-coated alginate beads was performed by conducting the activity measurement at time intervals of $15 \mathrm{~min}$. After each activity measurement, beads were separated by filtration and washed thrice with $5 \mathrm{ml}$ distilled water. Then fresh Tris- $\mathrm{HCl}$ buffer $(0.1 \mathrm{M}, \mathrm{pH} 8.0)$ and $p \mathrm{NPC}_{2}$ substrate were added to the beads and the next activity measurement was carried out and compared with the first run. Procedure was repeated for 10 times for silicate-coated and non-coated alginate beads separately. The first run activity was defined as $100 \%$.

Storage stability of immobilized esterase was investigated by incubation of alginate beads at 4 and $25^{\circ} \mathrm{C}$ for 3 -month period and the activity measurement under standard assay condition was performed at time intervals of ten days. Enzyme activity prior to incubation was defined as $100 \%$.

Kinetic parameters of immobilized esterase were determined using Lineweaver-Burk plots and assuming that the reactions followed a simple Michaelis-Menten kinetics. Lineweaver-Burk curves were obtained for $p N P C 2$ at six different substrate concentration $(0.05,0.1,0.3,0.5,0.7$ and $1 \mathrm{mM})$ using standard enzyme assay. 
Table 1

The effect of alginate, $\mathrm{CaCl}_{2}$ and esterase concentration on immobilization of thermophilic esterase.

\begin{tabular}{ccc}
\hline & Enzyme loading efficiency (\%) & Immobilization yield (\%) \\
\hline \multicolumn{2}{c}{ Alginate concentration (\%) $\left(0.5 \mathrm{M} \mathrm{CaCl}_{2}, 0.1 \mathrm{mg} / \text { mlesterase }\right)^{2}$} & 22.9 \\
1 & 54.3 & 44.1 \\
2 & 68.1 & 39.9 \\
3 & 72.8 & 37.2 \\
4 & 79.0 & \\
$\mathrm{CaCl}_{2}$ & concentration (M) (2\% alginate, $0.1 \mathrm{mg} /$ mlesterase) \\
0.1 & 65.0 & 27.9 \\
0.3 & 66.8 & 38.8 \\
0.5 & 68.1 & 43.2 \\
0.7 & 68.5 & 45.8 \\
0.9 & 68.0 & 45.1 \\
1.1 & 67.9 & 44.3 \\
Esterase concentration (mg/ml) (2\% alginate, $\left.0.7 \mathrm{M} \mathrm{CaCl}_{2}\right)$ \\
0.01 & 45.0 & 32.5 \\
0.1 & 68.5 & 45.8 \\
0.5 & 69.1 & 45.5 \\
1.0 & 68.9 & 45.0 \\
\hline
\end{tabular}

\section{Results and discussion}

In this study, thermoalkalophilic recombinant esterase enzyme was used for immobilization by entrapment in coated Ca-alginate beads. Heterologous expression of esterase enzyme was achieved in $E$. coli and the enzyme was efficiently purified to homogeneity before immobilization procedure. As a result of heterologous expression and purification of esterase, it has been indicated that approximately $30.0-50.0 \mathrm{mg}$ of purified active protein can be isolated with high specific activity [15].

\subsection{Optimum conditions for esterase immobilization}

In the case of entrapment of enzymes, optimization of the immobilization conditions improves their utilization [16], therefore different experimental conditions were studied for determining the optimum parameters for esterase immobilization. Since sodium alginate and $\mathrm{CaCl}_{2}$ concentration are major parameters for enzyme entrapment in gel beads due to gelation formation by cross-linking between alginate and $\mathrm{Ca}^{2+}$ ions, the immobilization process of purified thermoalkalophilic esterase enzyme was carried out varying concentration of alginate solution $1-4 \%(\mathrm{w} / \mathrm{v})$ using $0.01-1 \mathrm{mg} / \mathrm{ml}$ esterase and $0.1-1.1 \mathrm{M} \mathrm{CaCl}_{2}$ solution. The results of enzyme loading efficiency and immobilization yield for each parameter are shown in Table 1.

As is seen from the table, elevated alginate concentration has improved enzyme loading efficiency progressively whereas the best yield of immobilization was obtained at $2 \%(\mathrm{w} / \mathrm{v})$ sodium alginate. This increase in loading efficiency of esterase with high alginate concentration may be the results of strong tightly crosslinked gel formation and entrapment of the enzyme [17]. Low percent immobilization yield was obtained with $1 \%$ and more than $3 \%$ alginate concentrations, $22.9 \%$ and $39.9 \%$, respectively. At $1 \%$ alginate concentration, esterase may leak out of beads due to soft, unstable and flaccid beads formation during immobilization [18]. The decrease in activity of entrapped esterase using more than 3\% alginate concentration during bead formation could be explained as diffusion limitation of substrate in to entrapped enzyme [19]. Therefore, $2 \%$ alginate concentration was selected in our studies.

The effect of $\mathrm{CaCl}_{2}$ solution on enzyme loading efficiency and immobilization yield was studied and the maximum yield was observed at $0.7 \mathrm{M} \mathrm{CaCl}_{2}$ solution (Table 1 ). There was almost no effect of $\mathrm{CaCl}_{2}$ concentration on enzyme loading efficiency whereas the immobilization yield was small at below $0.5 \mathrm{M} \mathrm{CaCl}_{2}$ concentrations due to unstable cross-linked gel formation and dispersion of beads in a short time.

Different concentrations of esterase were used and the best enzyme loading efficiency and immobilization yield was observed as $68.5 \%$ and $45.8 \%$, respectively with $0.1 \mathrm{mg} / \mathrm{ml}$ esterase. At higher protein concentration, a saturation of immobilization was observed so that esterase concentration was fixed as $0.1 \mathrm{mg} / \mathrm{ml}$ for subsequent experiments. Consequently, the optimal conditions of esterase immobilization for the best activity were observed with $2 \%$ alginate using $0.5 \mathrm{mg} / \mathrm{ml}$ enzyme and $0.7 \mathrm{M} \mathrm{CaCl}_{2}$ solution. Although alginate as a biopolymer has been used to prepare microspheres as enzyme stabilization carriers which are utilized in industrial applications, it has some disadvantages such as mechanical instability which results in enzyme leakage out of polymeric membrane due to porous structure of alginate [13]. In fact, it was reported that if the entrapped enzyme leakage out of beads during the course of time as a result of the large pores of the alginate matrix is eliminated, enzyme activity could be improved $[17,19]$. In order to investigate leakage problem of entrapped esterase in alginate beads, alginate beads were coated with hexane and TEOS. The results have demonstrated that coating the surface of alginate beads with hexane and TEOS has enhanced immobilization efficiency and immobilization yield by $45 \%$ and $21 \%$, respectively due to enzyme stabilization and prevention of enzyme leakage from the alginate beads. Similar to our results here, esterase from Rhyzopus oryzae has enhanced enzyme immobilization parameters after silica coating that was attributed to the enzyme leakage prevention with better stability during enzymatic reaction.

The silica coating of alginate beads was characterized by several methods including FT-IR, SEM and EDX. The elemental analysis of the non-coated and silicate coated alginate beads were investigated by EDX analysis showing the presence of elemental Si in silicate coated alginate beads (Fig. 1). Changes in functional groups of alginate beads after silicate coating were characterized using FT-IR spectroscopy (Fig. 2). In the case of silicate coated alginate beads, new and sharper bands appeared at $1083 \mathrm{~cm}^{-1}, 965 \mathrm{~cm}^{-1}$ and $796 \mathrm{~cm}^{-1}$ that can be correlated with $\mathrm{Si}-\mathrm{O}-\mathrm{Si}$ stretching, which is also consistent with the studies of Hwang et al. [13]. The differences in surface morphologies of both silicate coated and non-coated alginate beads were also investigated using scanning electron microscope (SEM). SEM micrographs were shown for silicate coated and non-coated beads in Fig. 3. It was found out that the surface of silicate-coated alginate beads was different than noncoated alginate beads having a very compact, smooth and tight structure. In contrast, non-coated alginate beads surface have had some pores which may be the reason of enzyme leakage displaying lower enzymatic activity. Other researchers have also reported that surface modification of immobilized enzyme may prevent the leakage and keep the activity of enzyme by forming a physical barrier $[16,17,20]$.

Operational stability of an immobilized enzyme is very important parameter that determines the possible application of enzyme in large scale processes to reduce the operation cost in practical applications. Therefore, operational stability of entrapped esterase in both silicate coated and non-coated alginate beads was determined as cycles number of enzymatic reaction carried out in Tris- $\mathrm{HCl}$ buffer $(0.1 \mathrm{M}, \mathrm{pH} 8)$ at $55^{\circ} \mathrm{C}$ for $5 \mathrm{~min}$, using $p$ NPC2 as substrate. Specific activity of the immobilized enzyme in both cases was determined after each cycle of enzymatic reaction (Fig. 4). After three subsequent cycles, more than $80 \%$ of the enzyme activity in silicate coated alginate beads was maintained indicating a good operational stability of the immobilized enzyme. Meanwhile, immobilized esterase in non-coated alginate beads displayed a minor possibility of reuse with significant loss of original enzymatic activity after three subsequent cycles. Similar results was observed with other immobilized enzymes and reported that soft 


\section{A.Non-coated Ca-alginate \\ beads}

C:IXIUSRI2012IKimya BolumuIGulsah Sanli1120110Inoncoated-1.spc

Lable A:

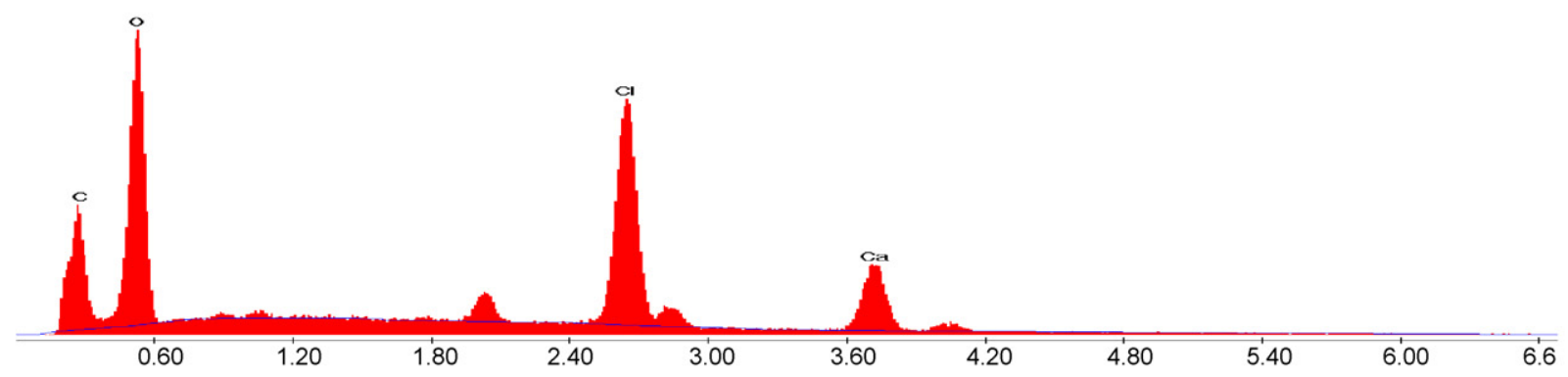

\begin{tabular}{ccc}
\hline Element & Weights $\%$ & Atomic \% \\
\hline C & 17.05 & 32.49 \\
O & 20.38 & 29.16 \\
Cl & 35.08 & 22.65 \\
Ca & 27.49 & 15.70 \\
\hline Total & 100.00 & 100.00 \\
\hline
\end{tabular}

\section{B. Silicate-coated Ca-alginate beads}

Lable A:

C:IxIIUSRI2012IKimya BolumulGulsah Sanlil120110Inoncoated-1.spc

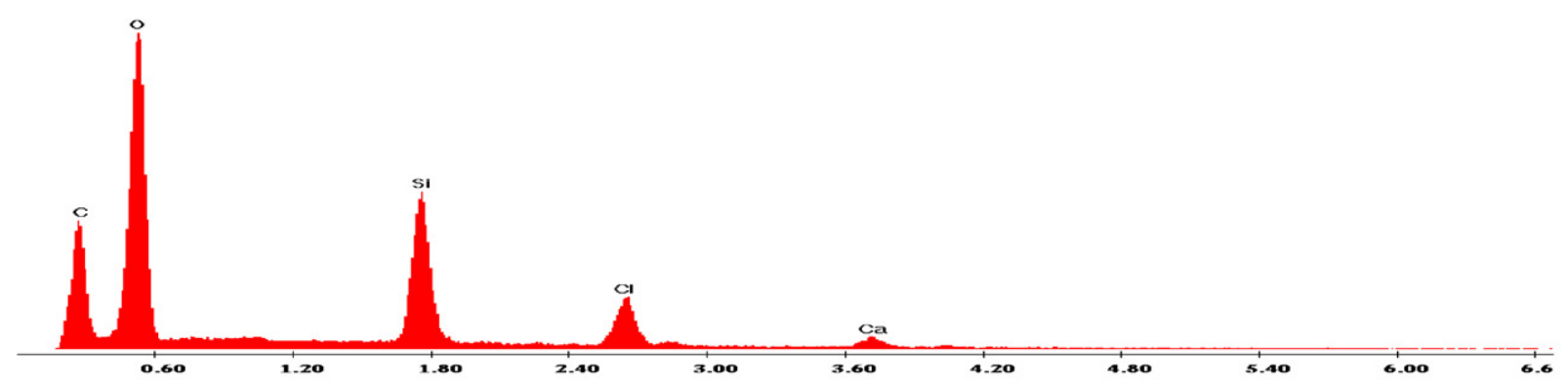

\begin{tabular}{ccc}
\hline Element & Weights \% & Atomic \% \\
\hline C & 26.79 & 40.37 \\
O & 32.37 & 36.62 \\
Si & 19.41 & 12.51 \\
Cl & 13.89 & 7.09 \\
Ca & 7.54 & 3.40 \\
\hline Total & 100.00 & 100.00 \\
\hline
\end{tabular}

Fig. 1. EDX spectrum of silicate-coated and non-coated Ca-alginate beads.

surface of non-coated beads compare to silicate coated alginate beads may be the reason for leakage of enzyme from the beads that results in loss of enzymatic activity after subsequent cycle in noncoated Ca-alginate beads $[16,17]$. The results prove that coating alginate beads with silicate is important for utilization of esterase in continuous processes. Compared to our results here, enhanced operational stability results by silicate coating were obtained by others in which entrapped enzyme was reused more than 10 times 


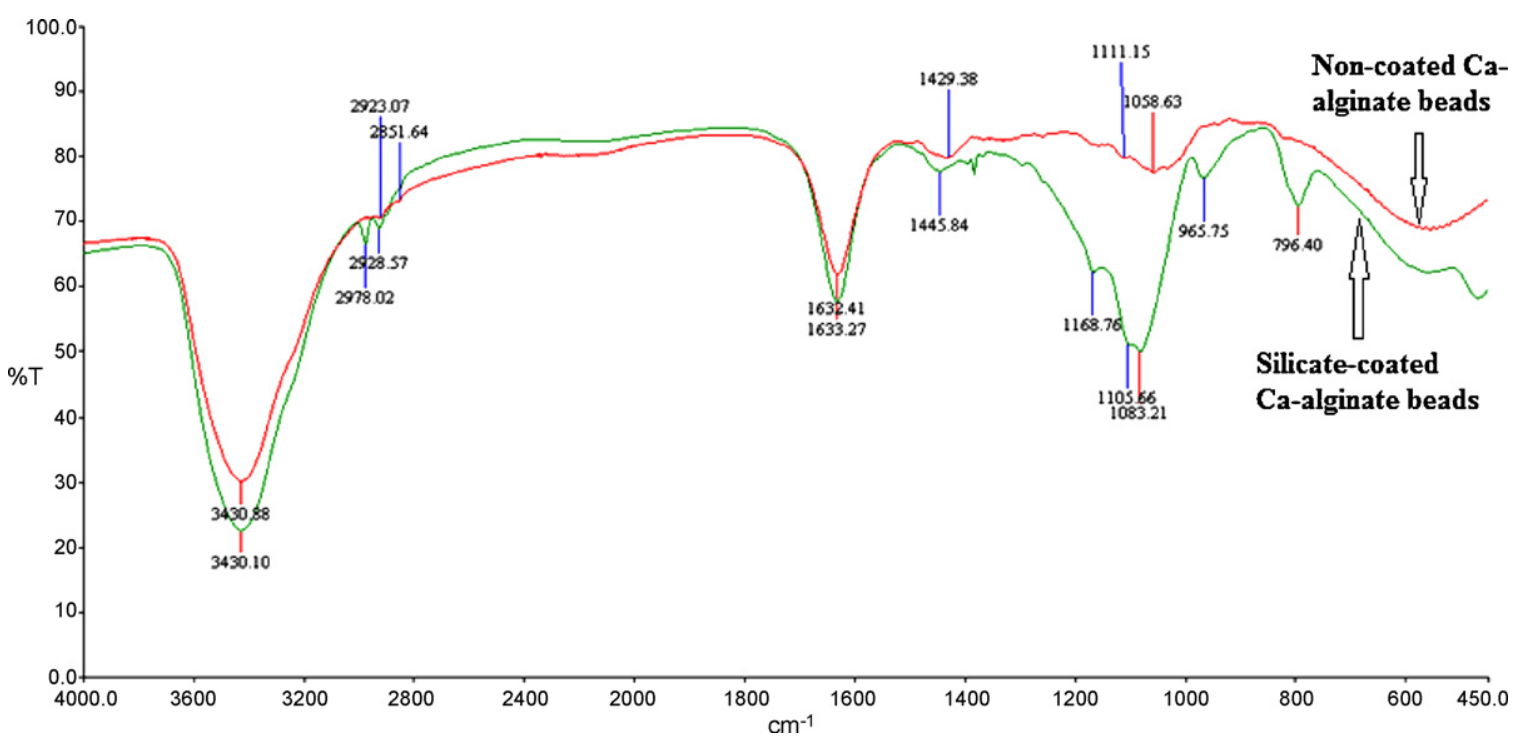

Fig. 2. FT-IR spectra of silicate-coated and non-coated Ca-alginate beads.

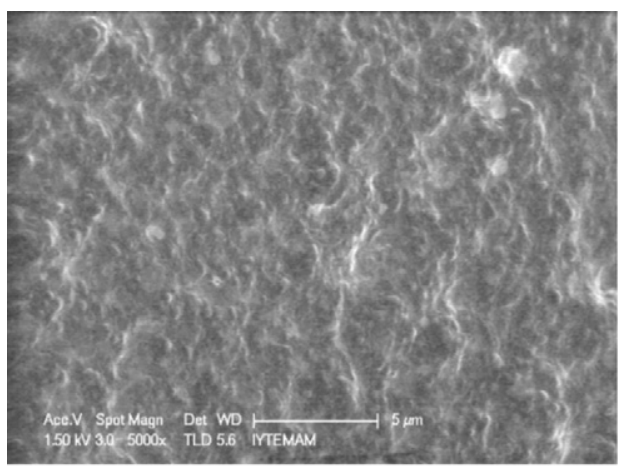

(a) Non-Coated bead

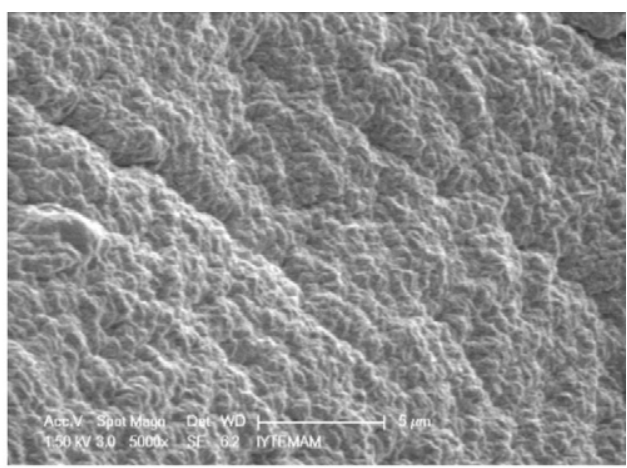

(b) Coated bead

Fig. 3. Comparison of silicate-coated and non-coated Ca-alginate beads surface by SEM.

after silicate coating with no significant loss of enzyme activity $[13,14]$.

The size of silicate coated alginate beads were investigated in terms of esterase activity as an important immobilization parameter in the case of entrapment of enzymes. The best esterase activity was observed with $0.5 \mathrm{~mm}$ diameter beads, the smallest

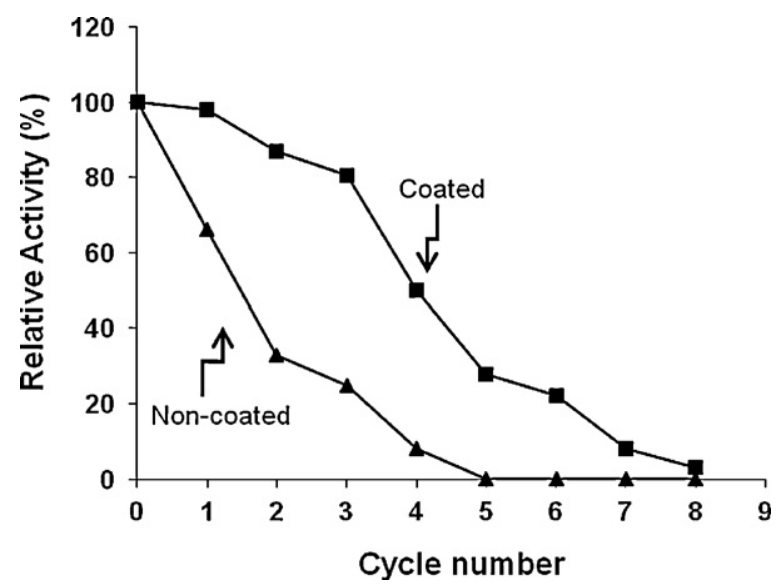

Fig. 4. Reusability of entrapped thermophilic esterase in both silicate coated and non-coated alginate beads. size obtained in our studies (Fig. 5). As other studies have reported that enzymes in smaller beads show higher catalytic activity due to reduced substrate transfer resistance and/or increase in surface area $[17,21]$.

\subsection{Characterization of free and immobilized thermoalkalophilic esterase}

The hydrolytic potential of free and immobilized thermoalkalophilic esterase were investigated by several parameters such as $\mathrm{pH}$, temperature, thermal stability and storage stability.

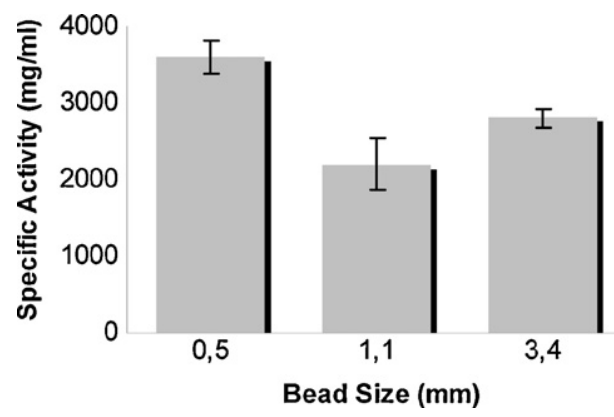

Fig. 5. Effect of different bead sizes on specific activity of thermophilic esterase. 


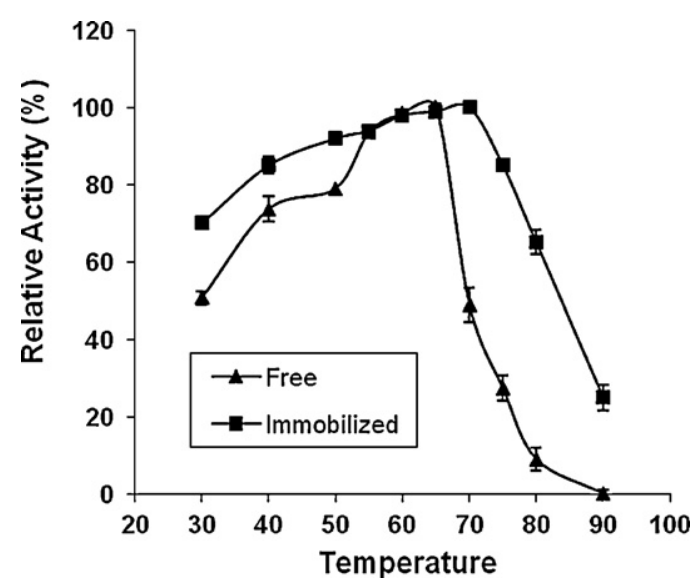

Fig. 6. Effect of temperature on the activity of free and immobilized thermophilic esterase.

The temperature dependence of the activities of both free and immobilized esterase were studied in the temperature range of $30-90^{\circ} \mathrm{C}$ and temperature profiles of free and immobilized esterase are presented in Fig. 6. The optimum temperature for free esterase was $65^{\circ} \mathrm{C}$. After immobilization of esterase in silicate coated alginate beads, it was found that the optimum temperature for immobilized esterase was shifted to $70^{\circ} \mathrm{C}$. The reason of this might be explained as physical limitation of esterase within micro spaces formed by entrapment inside of the beads and easy diffusion of the substrate to the active site at high temperature [22]. Therefore, the immobilized esterase showed its catalytic activity at a higher reaction temperature compared to that of the free enzyme. Results also suggest that the immobilization matrix might be able to protect the enzyme against denaturation at higher temperatures as was observed by other studies [19,22].

The effect of $\mathrm{pH}$ on the activity of the free and immobilized thermoalkalophilic esterase was assayed in the pH range of 4.0-11.0. Fig. 7 shows the response of free and immobilized esterase as a function of $\mathrm{pH}$. As can be seen from figure that free esterase exhibited maximum activity at $\mathrm{pH} 9$ whereas the maximum activity of immobilized esterase was observed at $\mathrm{pH}$ 8. In the case of silicate coated alginate beads, the optimum $\mathrm{pH}$ shifted by 1.0 unit toward the lower pH region (Fig. 7). Similar results were also observed with other studies and this behavior was attributed to the polymeric structure of Ca-alginate gel beads [19,23].

Thermal stability of enzyme is one of the important properties for its industrial applications that could be improved via

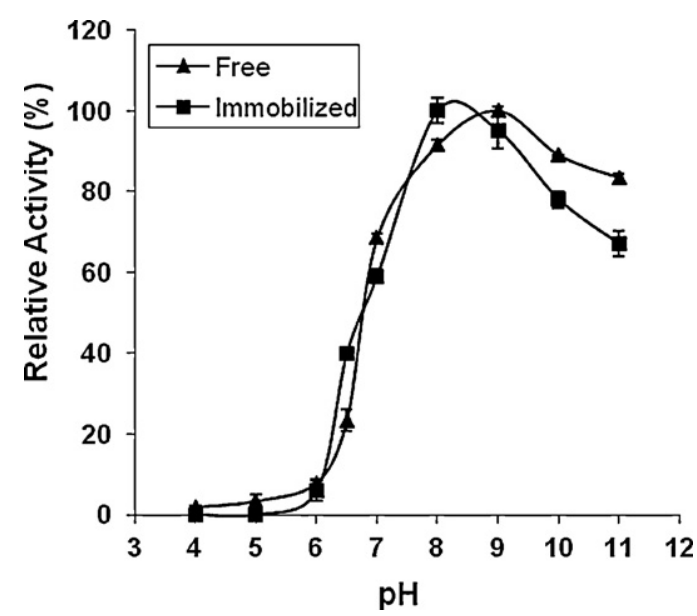

Fig. 7. Effect of pH on the activity of free and immobilized thermophilic esterase.

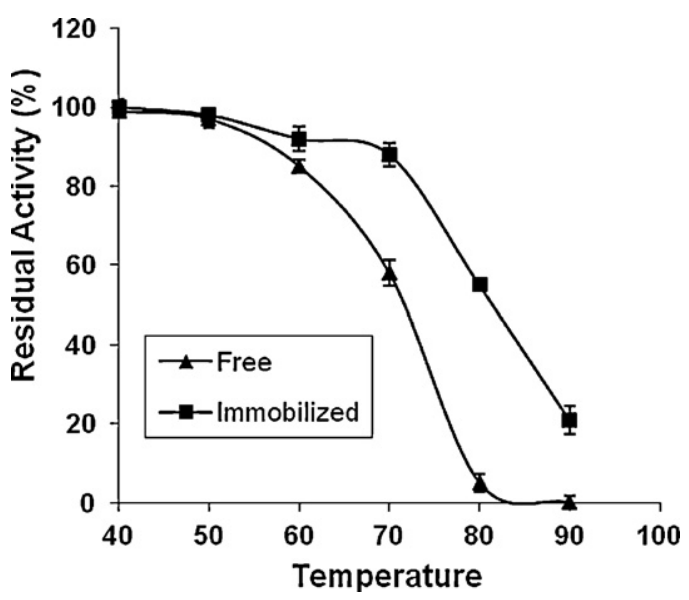

Fig. 8. Thermal stability of free and immobilized thermophilic esterase.

immobilization. The effect of temperature on the stability of free and immobilized thermoalkalophilic esterase in coated Ca-alginate beads was determined by incubating free and immobilized esterase in the absence of substrate at $40,50,60,70,80,90^{\circ} \mathrm{C}$ for $1 \mathrm{~h}$. Residual activity as a function of temperature is illustrated in Fig. 8. As can be seen from the figure, with increasing temperature immobilized esterase were inactivated at a much slower rate than those of the free esterase. The free and immobilized esterase remained completely stable for 1 h at $40-50^{\circ} \mathrm{C}$ and $40-55^{\circ} \mathrm{C}$, respectively. The stability of free and immobilized enzyme after $1 \mathrm{~h}$ at $60^{\circ} \mathrm{C}$ has begun to deviate and at $70^{\circ} \mathrm{C}$, the free and immobilized esterase retained their activity about to a level of $58,88 \%$ during $1 \mathrm{~h}$ incubation period, respectively. After $1 \mathrm{~h}$ at $80^{\circ} \mathrm{C}$ and $90^{\circ} \mathrm{C}$, the immobilized esterase retained $55 \%$ and $21 \%$ of its original activity, respectively, whereas the free one retained only $5 \%$ and $0 \%$, respectively (Fig. 8 ). It is often found out that immobilized enzyme has a higher thermal stability than that of free enzyme because of restriction of conformational movement in immobilized enzyme [24]. The better stability of an immobilized enzyme compared with the free form could be explained by the esterase location inside the micro space of the support, where the enzyme is protected against alterations of the microenvironment.

Storage stability is a very important parameter for the application of an enzyme on the commercial scale and it is well known that enzyme in solution is not stable during storage and the activity is gradually decreased by the time. In fact, immobilized enzymes display a good storage stability compared to free counterparts. Hence, storage stability of both free and immobilized esterase was investigated at 4 and $25^{\circ} \mathrm{C}$ for 3-month of period and the activity of the esterase was determined as a function of time. The results are given in Fig. 9. Under storage conditions, free enzyme lost about $29 \%$ and

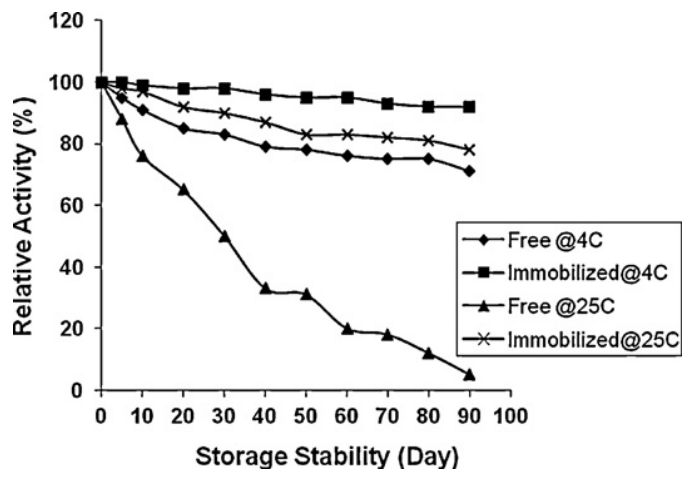

Fig. 9. Storage stability of immobilized esterase at $4{ }^{\circ} \mathrm{C}$ and $25^{\circ} \mathrm{C}$. 
$95 \%$ of its initial activity over the time at 4 and $25^{\circ} \mathrm{C}$, respectively. The immobilized esterase lost only about $8 \%$ and $28 \%$ of its activity over the same period of time at 4 and $25^{\circ} \mathrm{C}$, respectively. By this period, no enzyme release was observed therefore the decrease in activity can be explained as time dependent natural loss. These results indicated that storage stability of immobilized esterase was improved compared to free esterase. Similar observations have also been reported by other researchers [24,25]. The results indicated that the immobilized enzyme had good storage stability.

The kinetic parameters $\mathrm{Km}$ and kcat for immobilized esterase were determined by varying the $p \mathrm{NPC} 2$ concentration from 0.05 to $1 \mathrm{mM}$ in the reaction mixture. The immobilized esterase exhibited a simple Michaelis-Menten kinetics and Lineweaver-Burk plot showed a linear response over the tested concentration range. The $\mathrm{Km}$ and kcat values of immobilized esterase were estimated to be $0.11 \mathrm{mM}$ and $12,857 \mathrm{~s}^{-1}$. The $\mathrm{Km}$ value for immobilized esterase was lower than that of the free enzyme $(0.17 \mathrm{mM})$. The structural changes in the enzyme and/or steric limitations introduced by the immobilization may be attributed to this change in the enzyme affinity for its substrate. A decrease in the kcat value during the immobilization process is commonly observed because of limitations on diffusion [16].

\section{Conclusion}

For industrial applications, the immobilization of enzymes may offer several benefits over free enzymes. Through this study, due to special interest of esterase in a variety of biotechnological applications, for the first time we have used recombinant thermoalkalophilic esterase enzyme from Balçova Geothermal region for immobilization studies. Enzyme was immobilized effectively via a simple and cost-effective protocol using Ca-alginate by entrapment and optimal conditions were obtained with $2 \%$ alginate using $0.5 \mathrm{mg} / \mathrm{ml}$ enzyme and $0.7 \mathrm{M} \mathrm{CaCl}_{2}$ solution. In order to eliminate leakage problem of entrapped esterase in alginate beads, alginate beads were coated with hexane and TEOS. The results have demonstrated that silicate coated alginate beads enhanced immobilization and permitted reusability of esterase in continuous processes. The silica coating of alginate beads was characterized by several methods including FT-IR, SEM and EDX. Using the optimum immobilization conditions of esterase enzyme in silicate coated
Ca-alginate beads, the hydrolytic properties of free and immobilized enzyme in terms of storage and thermal stability as well as the effects of the temperature and $\mathrm{pH}$ were determined and compared.

\section{Acknowledgments}

The authors would like to thank Izmir Institute of Technology Research Foundation for financial support, to Center of Material Research at Izmir Institute of Technology for SEM and EDX analysis, to Dr. Hüseyin Özgener for his his valuable contributions on FT-IR analysis.

\section{References}

[1] U.T. Bornscheuer, FEMS Microbiol. Rev. 733 (2002) 1-9.

[2] T. Panda, B.S. Gowrishankar, Appl. Microbiol. Biotechnol. 67 (2005) 160-169.

[3] S. Khanna, K.K. Sekhon, N.T. Prakash, Cloning, Biotechnology 8 (2009) 235-241.

[4] S.B. Kim, W. Lee, Y.W. Ryu, Cloning, J. Microbiol. 46 (2008) 100-107.

[5] H.E. Ewis, A.T. Abdelal, C.D. Lu, Gene 329 (2004) 187-195.

[6] A. Kademi, N.A. Abdelkader, L. Fakhreddine, J.C. Baratti, Enzyme Microb. Technol. 24 (1999) 332-338.

[7] W. Tisher, V.V. Kasche, Trends Biotechnol. 17 (1999) 326-335.

[8] R.A. Sheldon, Adv. Synth. Catal. 349 (2007) 1289-1307.

[9] O. Smidsrod, G. Skjak-Brlk, Trends Biotechnol. 8 (1990) 71-78.

[10] M.M. Elnashar, E.N. Danial, G.E. Awad, Ind. Eng. Chem. Res. 48 (2009) 9781-9785.

[11] M.C. Levy, F. Edwards-Levy, J. Microencapsulation 13 (1996) 169-183.

[12] P. Matricardi, C.D. Meo, T.Coviello, F. Alhaique, Expert Opin. Drug Deliv. 5(2008) 417-425.

[13] E.T. Hwang, H. Lee, J.H. Kim, R. Tatavarty, M.B. Gu, J. Mater. Chem. 21 (2011) 6491-6493.

[14] S.W. Xu, Y. Lu, J. Li, Y.F. Zhang, Z.Y. Jiang, J. Biomater. Sci. Polym. Ed. 18 (2007) 71-80.

[15] H.C. Tekedar, G. Şanlı-Mohamed, Extremophiles 15 (2011) 203-211.

[16] Y.W. Zhang, P. Prabhu, J.K. Lee, Bioprocess Biosyst. Eng. 33 (2010) 741-748.

[17] K. Won, S. Kim, K.J. Kim, H.W. Park, S.J. Moon, Process Biochem. 40 (2005) 2149-2154.

[18] E. Quiroga, C.O. Illanes, N.A. Ochoa, S. Barberis, Process Biochem. 46 (2011) $1029-1034$.

[19] S. Kumar, A. Dwevedi, A.M. Kayastha, J. Mol. Catal. B: Enzym. 58(2009)138-145.

[20] K.H. Lee, P.M. Lee, Y.S. Siaw, J. Chem. Technol. Biotechnol. 57 (1993) 27-32.

[21] I. Bhushan, R. Parshad, G.N. Qazi, V.K. Gupta, J. Bioact. Compat. Polym. 23 (2008) 552-562.

[22] F. Kara, G. Demirel, H. Tümtürk, Bioprocess Biosyst. Eng. 29 (2006) 207-211.

[23] Z.D. Zhou, G.Y. Li, Y.J. Li, Int. J. Biol. Macromol. 47 (2010) 21-26.

[24] F.Ş. Yahşi, G. Demirel, H. Tümtürk, Int. J. Biol. Macromol. 36 (2005) 253-258.

[25] H. Tümtürk, G. Demirel, H. Altınok, S. Aksoy, N. Hasırcı, J. Food Biochem. 32 (2008) 234-246. 